\title{
METODE IJTIHAD T. M. HASBI ASH-SHIDDIEQY SEBAGAI PRODUK PEMIKIRAN HUKUM ISLAM
}

\author{
Muhammad Hasbi \\ Sekolah Tinggi Agama Islam Negeri (STAIN) Watampone \\ Email:muh.hasbi@yahoo.co.id
}

\begin{abstract}
This paper will examine the method of ijtihad Hasbi Ash-Shiddieqy in giving birth to Islamic legal thought products. Ijma ', qiyas, Istihsan, maslahah al-mursalah, and' urf is a method or means in producing law as a product of Islamic legal thought. The five principles that enable Islamic law to develop in keeping with the times, namely; first; principle of ijma '. Second, the principle of qiyas. Third; maslahah al-mursalah. Fourth; maintenance 'urf. Fifth; changing law with changing times.
\end{abstract}

Abstrak: Tulisan ini akan mengkaji metode ijtihad Hasbi Ash-Shiddieqy dalam melahirkan produk pemikiran hukum Islam. Ijma', qiyas, Istihsan, maslahah almursalah, dan 'urf merupakan sebuah metode atau sarana dalam menghasilkan hukum sebagai produk pemikiran hukum Islam. Kelima prinsip yang memungkinkan hukum Islam berkembang dalam mengikuti perkembangan zaman, yaitu; pertama; prinsip ijma'. Kedua, prinsip qiyas. Ketiga; maslahah al-mursalah. Keempat; pemeliharaan 'urf. Kelima; berubahnya hukum dengan berubahnya masa.

Kata Kunci : Ijtihad, Istinbath dan Hukum Islam

\section{PENDAHULUAN}

Para ulama Islam dituntut untuk melakukan upaya rekonstruksi terhadap khazanah pengetahuan Islam secara inovatif dalam menghadapi perkembangan ilmu pengetahuan dan teknologi yang begitu pesat dalam beberapa bidang kehidupan masyarakat dewasa ini.

Masyarakat Islam, sebagai suatu bagian yang tak dapat melepaskan diri dari persoalan-persoalan baru yang berkembang dalam masyarakat. Persoalan-persoalan baru yang status hukumnya sudah jelas dan tegas dinyatakan dalam al-Qur'an dan al-
Sunnah tidak akan menimbulkan pro dan kontra dikalangan umat Islam. Termasuk yang cukup urgen, adalah upaya para ulama untuk secara terusmenerus melakukan ijtihad $^{1}$ di bidang fikih. Sebab kajian soal ijtihad akan selalu aktual, mengingat kedudukan dan fungsi ijtihad dalam yurisprudensi Islam tidak dapat dipisahkan dengan produkproduk fikih. Dalam kondisi demikian, muncul perbedaan pendapat ada yang membolehkan suatu tindakan di satu pihak, dan ada pula yang tidak membolehkan di pihak lain.

T. M. Hasbi ash-Shiddieqy adalah salah seorang ulama Indonesia yang 
pikiran-pikirannya banyak menjadi rujukan dan telah berhasil menyumbangkan beberapa banyak karya-karyanya, baik di bidang tafsir, ibadah dan fikih. Dan menjadi kajian dalam tulisan ini adalah masalah metode ijtihad T. M. Hasbi Ash-Shiddieqy dalam melahirkan produk pemikiran hukum Islam

\section{PEMBAHASAN}

\section{A. Pengertian Ijtihad}

Secara etimologi, ijtihad berakar pada kata ج yang berarti kesulitan atau kesusahan ${ }^{2}$. Menurut Prof. Dr. H. Minhajuddin, MA., bahwa ijtihad berarti mencurahkan segala kemampuan atau menanggung beban yang berat. $^{3}$ Menurut Wahbah Zuhayliy :

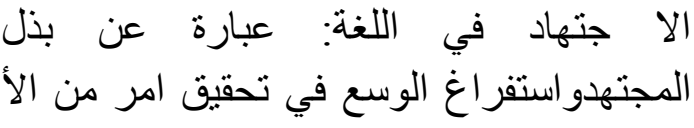

"Ijtihad menurut bahasa ialah mengerahkan dari segala kesungguhan dan mencurahkan segala kemampuan dalam menguatkan suatu urusan dari berbagai urusan". 4

Kalau lebih disederhanakan perumusannya, maka ijtihad bermakna kerja keras dan bersungguh-sungguh. Dengan demikian, setiap pekerjaan yang dilakukan dengan maksimal serta mengerahkan segenap kemampuan yang ada, dinamakan ijtihad pelakuknya dinamai mujtahid.

Kemudian kata atau istilah ijtihad tersebut digunakan sebagai salah atau istilah dalam kajian ilmu usul al-fiqh yang bermakna usaha maksimal ulama fikih dalam melakukan kajian untuk memperoleh ketentuan-ketentuan hukum yang bersifat danniy. ${ }^{5}$

Lebih lanjut Wahbah Zuhayliy mengemukakan pengertian Ijtihad menurut Istilah bahwa:

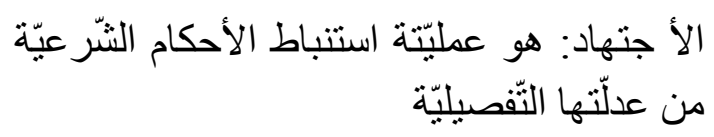

"Ijtihad adalah usaha mengistinbatkan hukum-hukum syara' dari dalinya secara terperinci."6

'Abd al-Wahhab Khallaf mendefinisikan bahwa Ijtihad sebagai pengerahan daya upaya untuk sampai kepada hukum syara' dari dalil yang terperinci dengan bersumber dari dalildalil syara'. 7 Muhammad Abu Zahrah mengatakan bahwa ijtihad adalah sebagai daya upaya ahli hukum Islam semaksimal mungkin dalam mengistimba ${ }^{-}$-kan hukum praktis dari dalildalilnya yang terperinci. ${ }^{8}$ Muhammad Musa Tuwana juga memberikan defenisi ijtihad yang senada, yakni pegerahan segala daya upaya ahli hukum Islam dalam menggali hukum-hukum syara' yang berstatus cabang dan dalildalilnya. ${ }^{9}$

Menurut T. M. Hasbi AshShiddieqy bahwa ijtihad adalah:

$$
\text { بذل الجهد لتحصيل حكم شرعيّ }
$$

"Memberi segala daya kemampuan dalam usaha mengetahui suatu hukum syara'".

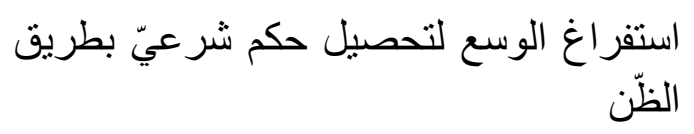


"Mencurahkan segala kesanggupan untuk mencari sesuatu hukum dengan jalan dhann. ${ }^{10}$

\section{B. Lapangan Ijtihad}

Apabila nass yang kita hadapi, tegas sarih lagi qat'iyy al-wur-d-nya (kedatangannya dari syara') dan qat'iyy al-dalalah-nya (pasti penunjukannya kepada makna tetentu), maka tak ada ijtihad padanya. Maka kita wajib tatbiqkannya sebagaimana yang dikehendaki oleh nass itu, karena dia qat'iyy alwurud-nya, dia tak dibahas lagi dan karena dia qat'iyy al-dalalah-nya, tak ada tempatnya lagi kita membahas ma'nanya. ${ }^{11}$

Menurut Minhajuddin selama nass itu qat'iyy al-wurud, maka kepastian dan kehadirannya dalil-dalil itu dari sisi Tuhan atau Rasul-Nya bukan lagi menjadi ajang pembahasan yang membuang energi itu. Lebih lanjut dikatakan bahwa selama nass itu qat'iyy al-dalalah tidak ada tempat untuk membahas dan ber-ijtihad tentang dalalah maknanya dan ketetapan hukumnya. ${ }^{12}$

Di antara yang demikian, ialah ayatayat ahkam yang mufassalah dan muhkamah, seperti Firman Allah:

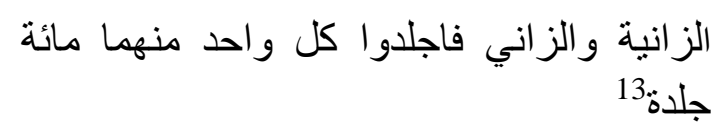

"Pezina perempuan dan pezina laki-laki jilidlah masing-masing dari keduanya seratus kali jilid."

Apabila nas yang kita hadapi §anniy al-wurud-nya atau §anniy dalalah-nya, dialah yang diperlukan ijtihad.
Para mujtahid harus membahas dalil itu dari segi sanad dan jalan sampainya kepada kita dan dari jurusan dalalah-nya kepada makna, agar sampailah kita kepada mengetahui hukumnya dengan jalan-jalan qiyas, istihsan, istishab, istislah. Bidang ijtihad (majal al-ijtihad) sangatlah luas dalam soal-soal yang tak ada nass. Dalam soal-soal yang telah ada nass tak ada ijtihad lagi. ${ }^{14}$

\section{Ijtihad Jama'iy dan Fardiy}

Pada prinsipnya ijtihad dapat dibagi ke dalam dua bagian, yakni ijtihad kolektif (jama'iy) dan ijtihad perseorangan (fardiy). Pembagian ijtihad atas dua kategori seperti telah disebutkan berdasarkan pada praktek ijtihad sejak masa Nabi Muhammad Saw. ${ }^{15}$

Ijtihad perseorangan ialah ijtihad yang dilakukan secara mandiri oleh seseorang yang mempunyai keahlian, dan hasil ijtihad-nya sebelum mendapat persetujuan ulama atau mujtahid lain. Ijtihad ini diakui dalam Islam dan merupakan hak setiap muslim yang memiliki keahlian dalam menganalisis dan mengkaji suatu masalah secara mendalam. Ijtihad semacam ini tidak merupakan kewajiban bagi orang lain untuk mengikutinya. Pengamalan ijtihad fardiy hanya menjadi kewajiban bagi orang yang menghasilkannya. ${ }^{16}$

Hasbi mengatakan bahwa ijtihad fardiy itulah yang dibenarkan Rasulullah kepada Mu'az. Dan ijtihad inilah yang ditekankan Umar kepada Abu Musa al-Asy'ariy kepada Syuraih.

Umar mengatakan kepada Syuraih:

$$
\text { وما لم يتبين للك فى السّنة فجتهد فيه رأيك }
$$


"Dan apa yang tidak nyata kepada engkau dalam al-sunnah, maka berijtihad-lah dengan menggunakan daya fakir engkau".

Lebih lanjut Hasbi mengungkapkan bahwa yang masuk dalam ijtihad ini, seperti pendapat Ibn Mas'ud tentang wanita yang suaminya meninggal sebelum disetubuhi dan ditentukan jumlah mahar. Sudah sebulan lamanya Ibn Mas'ud berfikir beliaupun menetapkan bahwa jumlah mahar wanita itu adalah sejumlah mahar yang biasa diterima oleh wanita-wanita yang setara dan wanita itu mendapat pusaka serta harus beridda. ${ }^{17}$

Sedangkan ijtihad Jama'iy ialah ijtihad terhadap sesuatu masalah yang disepakati oleh semua mujtahid. Ijtihad inilah yang dimaksudkan oleh hadi£ '2li diwaktu beliau menanyakan kepada Rasul tentang sesuatu urusan yang menimpa masyarakat yang tidak ditentukan hukumnya dalam al-Qur'an dan al-Sunnah. Nabi bersabda:

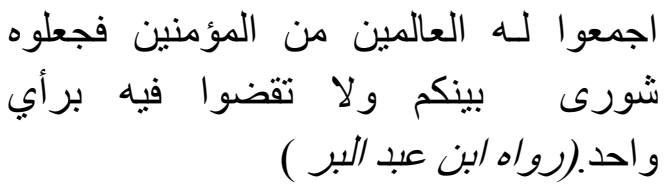

"Untuk menghadapi masalah itu, Kumpulkanlah orang-orang yang berilmu dari orang-orang mukmin dan jadikanlah hal ini masalah yang dimusyawarakan di antara kamu dan janganlah kamu memutuskan hal itu dengan pendapat orang seorang." (H.R. Ibn Abdil Barr)
Di antara ijtihad jama'iy, kesepakatan sahabat untuk mengangkat Abu Bakar menjadi kepala negara dan kesepakatan mereka terhadap tindakan Abu Bakar yang menyetujui 'Umar sebagai penggantinya dan sebagai kesepakatan mereka menerima anjuran 'Umar supaya al-Qur'an ditulis di dalam Mushaf. Pada hal yang demikian itu tidak dilakukan di masa Rasul dan seperti kesepakatan mereka memperserikatkan ibu dari ayah bersama dengan ibu dari ibu dalam menerima $1 / 6$ harta peninggalan, pada hal mulamulanya Abu Bakar memberikan kepada ibu dari ibu saja. ${ }^{18}$

\section{Syarat - Syarat Mujtahid dan Tingkatannya.}

Mujtahid ialah orang yang memiliki syarat ijtihad yang sempurna, mempunyai kemampuan untuk mengistimbatkan hukum-hukum amaliyah dari dalil-dalil syar'i. Merekalah yang dinamakan mufti dan faqih pada masa dahulu. ${ }^{19}$

Syarat-syarat yang diperlukan pada Mujtahid:

1. Mengetahui dengan sempurna hukum al-Qur'an dan hukumhukum Sunnah, dasar-dasar syariat yang umum. Dia harus mengetahui ayat-ayat hukum dan hadif-hadif hukum, mengetahui sebab-sebab nuzul, sebab wur-d, sah tidaknya hadis, nasikh mans-kh, mutawatir dan masyh-r. Dalam hal ini dia cukup mengetahui tempat memperoleh dalil-dalil itu. ${ }^{20}$ 
2. Mengetahui hukum-hukum yang telah di ijma'iy dan yang diperselisihkan. $^{21}$

3. Mengetahui illat-illat hukum dan jalan-jalan menggali illat-illat itu dari dalil serta petunjuk lafaz kepada makna dan mengetahui maksud-maksud syara', rahasiarahasia tasyri', maslahah almursalah dan 'urf masyarakat.

4. Mengetahui bahasa Arab, hal ini perlu untuk mengetahui nass. Selain dari itu hendalah mujtahid itu orang yang adil, melaksanakan sendiri hukumhukum yang telah diijtihadkan. ${ }^{22}$ Dan sebagian ulama menambah pula supaya mujtahid itu Islam.

Selain syarat-syarat seorang mujtahid yang telah diungkapkan tersebut di atas, maka ada juga yang berpandangan bahwa seseorang bisa melakukan kegiatan ijtihad, jika memenuhi dua pensyaratan utama, yaitu penyaratan keagamaan ${ }^{23}$ dan penyaratan keilmuan. $^{24}$

Prof. T. M. Hasbi Ash-Shiddieqy mengemukakan syarat-syarat dan tingkatan mujtahid sebagai berikut:

1. Menguasai ilmu bahasa Arab dengan segala cabangnya. ${ }^{25}$

2. Mengetahui nass al-Qur'an. ${ }^{26}$

3. Mengetahui nass al-hadif. ${ }^{27}$

4. Mengetahui maqasid al-syari'ah. ${ }^{28}$

Dilihat dari luas atau sempitnya cakupan bidang ilmu yang dijtihadkan Mujtahid itu terbagi dalam empat tingkatan, yaitu: (1) Mujtahid fi alSyar'i, (2) Mujtahid fi al-Ma@hab, (3)
Mujtahid fi al-Masa'il, dan (4) Mujtahid Muqayyad. ${ }^{29}$

\section{Dalil dan Metode Ijtihad Hasbi Ash-Shiddieqy dalam Melahirkan Produk Pemikiran Hukum Islam}

Di bawah ini akan dikemukakan bagaimana alur pemikiran Hasbi AshShiddieqy:

1. Pandangannya tentang al-Qur'an

Sebagaimana ulama lainnya bahwa al-Qur'an adalah dasar asasi bagi segala dasar syari'at atau masdar al-masadir. Dan bahkan seluruh umat Islam menetapkan bahwa al-Qur'anlah dasar satu-satunya yang tidak diperselisihkan dalam menerimanya sebagai hujjah. ${ }^{30}$ Apakah terjemahan al-Qur'an termasuk al-Qur'an atau tidak? Menurut Hasbi Ash-Shiddieqy bahwa terjemahan alQur'an tidak dapat dipandang sebagai al-Qur'an. Lantaran ini, tiada sah kita bersembahyang dengan membaca terjemahannya. Kita diperintahkan membaca al-Qur'an, terjemahannya itu bukan al-Qur'an.

\section{Al-Sunnah}

Al-Sunnah adalah perkataanperkatan nabi, perbuatan-perbuatan Nabi dan takrir-takrirnya. Al-Sunnah itulah dasar yang kedua dipegangi oleh imam empat Mazhab.. Martabat al-sunnah dibawah martabat al-Qur'an dan alSunnah adalah jalan memahami alQur'an. Secara ringkas bahwa al-sunnah mempunyai hak dalam menetapkan hukum.

Bebeda dengan al-Gazali, menurut al-Gazali bahwa al-Qur'an dan al-Sunnah berada dalam satu martabat, ia 
menempatkan al-Sunnah sejajar dengan al-Qur'an, karena sunnah nabi pada hakekatnya bersifat bayan terhadap alQur'an. ${ }^{31}$

\section{Ijma'}

Jumhur Ulama usul fiqh berpendapat bahwa apabila rukun ijma ${ }^{32}$ telah terpenuhi, maka ijma' tersebut menjadi hujjah yang qat'iy (pasti) wajib diamalkan dan tidak boleh mengingkarinya; bahkan orang mengingkarinya dianggap kafir. Di samping itu, permasalahan yang telah ditetapkan hukumnya melalui ijma', menurut para ahli usul figh, tidak boleh lagi menjadi pembahasan ulama generasi berikutnya, karena hukum yang ditetapkan melalui ijma' merupakan hukum syara' yang qat'iy yang menempati urutan ketiga sebagai dalil syara' setelah al-Qur'an dan Sunnah. ${ }^{33}$

Akan tetapi, tokoh Mu'tazilah (Ibrahim ibn Siyar al-Nazzam), ulama Khawarij dan ulama Syi'ah ${ }^{34}$ berpendapat bahwa ijma' tidak dapat dijadikan hujjah.

Hasbi Ash-Shiddieqy mengikuti pendapat para ulama Usul fiqh, menetapkan bahwa ijma' itu dapat dijadikan hujjah, menetapkan pula bahwa ijma' terletak di bawah derajat Kitabullah dan Sunnah Rasul dan ijma' itu tidak boleh menyalahi nass yang qat'iy (Kitabullah dan hadis yang masyh-r). ${ }^{35}$

Kebanyakan ahli Usul menetapkan bahwa ijma' menurut makna atau takrif yang diberikan oleh kebanyakan ahli $u s-l$ dipandang suatu dasar dari dasar-dasar syari'at. Akan tetapi, jika masalah ini akan dibahas dengan seksama ditinjau dari segala aspeknya, jelas bahwa: masalah menjadikan ijma' sebagai dasar agama atau hujjah, bukan masalah yang disepakati. Banyak di antara ulama mujtahidin, walaupun mereka membenarkan takrif ijma', tetapi mereka menetapkan bahwa ijma' tidak mungkin terjadi, apalagi saat sekarang ini.

Kalau demikian tidak ada artinya kita berhujjah dengan dalil tersebut, karena tak pernah terjadi. Tegasnya, tak dapat seorang berkata: Ini haram atas dasar ijma'. Oleh karena itu, walaupun ijma' dibenarkan menurut takrif sebagai hujjah agama, namun tak pernah terjadi.

Namun, menurut Hasbi AshShiddieqy bahwa ijma' yang tidak bisa dilepaskan ilah ijma' Sahabat dan ulama Salaf Mutaqaddimin yang sah dan jelas, teristimewa dalam soal aqidah dan ibadah. Adapun hasil ijma' mutaakhkhirin perlu diteliti keabsahannya. Sebab, seringkali apa yang dikatakan hasil ijma' para ulama mutakhkhirin, hanyalah ijma' ulama di kalangan ma@hab tertentu saja. ${ }^{36}$

Lebih lanjut menurut Hasbi AshShiddieqy, ada dua bentuk lembaga $A h l$ al-Halli wa al-'Aqdi yang diinginkan oleh para pemikir Muslim. Pertama; berbentuk Lembaga Perwakilan Rakyat. Kedua; bentuk Lembaga yang beranggotakan ulama dan ilmuwan. ${ }^{37}$ Ia mengatakan bahwa Ahl al-Halli wa al'Aqdi yang bertugas memilih kepala negara disebut haiah siyasah (lembaga politik). Seperti di Indonesia yaitu eksekutif/presiden dan legislatif (MPR/DPR), akan tetapi, di Indonesia 
pada PEMILU 2004 bukan lagi MPR yang memilih Presiden, tetapi pemilihan langsung artinya rakyat yang langsung memilih tanpa melalui perwakilan, sedangkan ahl al-ijtihad yang bertugas menetapkan hukum disebut haiah tasyi'iyyah (lembaga pembinaan hukum). ${ }^{38}$ Kalau di Indonesia Mahkamah Agung (MA) atau biasa disebut dengan lembaga yudikatif.

\section{Qiyas $^{39}$}

Para mujtahidin berbeda pendapat tentang mempergunakan qiyas. Jumhur Ulama Usul fiqh berpendirian bahwa qiyas dapat dijadikan sebagai metode atau sarana untuk mengistibatkan hukum syara. $^{40}$

Sementara Ulama ahiriyyah, termasuk Imam al-Syaukaniy berpendapat bahwa secara logika, qiyas memang boleh, tetapi tidak ada satu nass pun dalam ayat al-Qur'an menyatakan wajib melaksanakannya. ${ }^{41}$

Menurut Hasbi Ash-Shiddieqy yang mengikuti pendapat para ahli usul yang mempergunakan qiyas sebagai dalil menetapkan hukum, bahwa qiyas itu barulah dipandang sah apabila lengkap dengan rukunnya. Contohnya: Pokok (asl), ialah tempat meng-qiyas-kan hukum, seperti "arak". Cabang (furu'), yang diqiyas-kan, seperti segala minuman yang memabukkan. Hukum asal (hukm al-asl), seperti haram segala minuman yang memabukkan. Sebab ('illat), seperti mabuk merusak akal. ${ }^{42}$

'Illat merupakan penyebab adanya hukum, dalam arti adanya suatu 'Illat menyebabkan munculnya hukum, misalnya wajibnya hukum potong tangan bagi pencuri, disebabkan karena perbuatan mencuri yang dilakukan. Akan tetapi, hukuman potong tangan sendiri pada hakikatnya merupakan kehendak Allah, bukan semata-mata karena perbuatan mencuri itu sendiri. Contoh lain, seorang pembunuh terhalang mendapatkan warisan dari harta orang yang ia bunuh, disebabkan pembunuhan yang ia lakukan. Dalam kasus, bukan karena membunuh semata-mata ---yang menjadi 'illat---yang menyebabkan ia tidak mendapatkan warisan, tetapi atas perbuatan dan kehendak Allah. Dengan demikian 'illat merupakan penyebab atau motiv dalam suatu hukum yang dapat dijadikan ukuran untuk mengetahui suatu hukum.

5. Istihsan $^{43}$

Terdapat perbedaan pendapat ulama usul figh dalam menetapkan istihsan sebagai salah satu metode atau dalil dalam menetapkan hukum syara'.

Menurut ulama Hanafiyah, Malikiyah dan sebagian ulama Hanabilah, istihsan merupakan dalil yang kuat dalam menetapkan hukum syara'. Alasan mereka kemukakan:

a. Ayat-ayat yang mengacu kepada mengangkatkan kesulitan dan kesempitan dari umat manusia, yaitu firman Allah surat al-Baqarah, 2: 185:

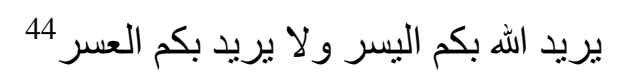

"Allah menghendaki kemudahan bagi kamu dan tidak menghendaki kesukaran bagi kamu".

b. Apabila seorang mujtahid dalam menetapkan hukum memandang 
bahwa kaidah umum atau qiyas tidak tepat diberlakukan, maka ia boleh berpaling kepada kaidah lain yang akan dapat memberikan hukum yang lebih sesuai dengan kemaslahatan umat manusia.

Sementara yang menolak istihsan adalah ulama Syafi'iyyah, aahiriyyah, ${ }^{45}$ Syi'ah dan Mu'tazilah ${ }^{46}$ tidak menerima istihsan sebagai salah satu metode atau dalil dalam menetapkan hukum syara'. ${ }^{47}$

Menurut Hasbi Ash-Shiddieqy bahwa istihsan adalah suatu dalil yang terkuat, menunjukkah bahwa hukum Islam adalah suatu hukum yang berkembang dalam masyarakat yang diistilahkan dengan fiqh waq'iy bukan suatu fiqh khayaliy merupakan fikih bayangan sebagai suatu yang digambarkan oleh sebagaian orang yang tidak mengetahui hakekat hukum Islam atau ingin menjauhkan manusia dari padanya.

Lebih lanjut ia mengatakan mudahmudahan kita dapat mewujudkan ahliahli hukum yang pandai mempergunakan dasar istihsan dalam menghadapi perkembangan masyarakat Islam di Indonesia. Dengan mempegunakan dasar istihsan ini mungkin dapat kita menghadapi masalah perbankan yang telah menjadi masalah yang sangat dipentingkan di dalam membangun masalah ekonomi. ${ }^{48}$ Contoh: Salah satu bentuk kerja sama yang dikelolah oleh perbankan syari'ah atau Bank Mu'amalah adalah mu«arabah (kerja sama dengan pemilik pemilik modal dengan pengelolah modal dalam perdagangan dengan perjanjian bagi hasil) sesuai dengan ketentuan kaidah umum, akad ini tidak dibolehkan, karena objek akan ini, sesuatu yang belum ada dan imbalan bagi pengelolah modal pun masih bersifat spekulatif. Akan tetapi, demi menghindari dan untuk kepentingan orang banyak akad ini dibolehkan oleh syara'.

Oleh kerena itu, istihsan dalam kebanyakan bentuknya merupakan pengecualian dari pada umum, maka bolehlah kita qiyaskan kepadanya sesuatu yang lain apabila cukup syaratsyarat qiyas. $^{49}$

\section{Maslahah al-Mursalah}

Salah satu metode yang dikembangkan ulama $u s-l$ figh dalam mengistimbatkan hukum dari nass adalah maslahah ${ }^{50}$ al-mursalah, yaitu suatu kemaslahatan yang tidak ada nass $j u z^{\prime} i$ (rinci) yang mendukungnya, dan tidak ada pula yang menolaknya dan tidak ada pula ijma' yang mendukunnya, tetapi kemaslahatan ini didukung oleh sejumlah nass.

Kehujjaan maslahah al-mursalah pada prinsipnya Jumhur Ulama menerimanya sebagai salah satu alasan dalam menetapkan hukum syara' sekalipun dalam penempatan syaratsyaratnya berbeda pendapat. ${ }^{51}$ Menurut Hasbi Ash-Shiddieqy mengatakan bahwa berhujjah dengan maslahah al-mursalah dan membina hukum atasnya adalah suatu keharusan. Inilah yang sesuai dengan keumuman syari'at. ${ }^{52}$

Dengan demikian, hukum-hukum Islam dapat berjalan seiring dengan masa dan inilah jalan yang ditempuh oleh para sahabat. Menolak maslahat, berarti 
membekukan syari'at, karena aneka maslahat yang terus tumbuh tidaklah mudah didasarkan kepada sesuatu dalil yang tertentu. Berpegang kepada maslahat tiadalah berlawanan dengan kesempurnaan syari'at, bahkan dialah yang membuktikan kesempurnaannya dan kemampuannya yang memenuhi hajat masyarakat dan kebutuhan masyarakat yang berbeda-beda keadaannya, karena berlainan tempat dan kita terus menerus menghadapi problema-problema baru.

Salah satu contoh yang popular dalam pergaulan kita, ialah mengangkat sesorang menjadi ketua, sudah beberapa bulan dia diangkat, ketahuanlah bahwa ada orang lain yang lebih cakap untuk jabatan ketaua itu. Dan menurut kepentingan lembaga, dialah yang harus memegang jabatan itu. Akan tetapi, jika diberhentikan niscaya ketua yang telah ada itu merasa tidak enak dan mungkin menimbulkan keonaran dalam lembaga. Sebab itu, menurut hukum maslahah almursalah biarlah jabatan itu sementara tetap sebagai yang telah ada untuk menghindari keonaran dan kekacauan.

7. 'Urf ${ }^{53}$

Menurut Mustafa Ahmad al-Zarqa' (guru besar fiqh Islam di Univesritas 'Amman, Jordania) mengatakan bahwa 'urf merupakan bagian dari adat, karena adat lebih umum dari 'urf. Suatu 'urf menurutnya harus berlaku pada kebanyakan orang di daerah tertentu, bukan pada pribadi atau kelompok tertentu dan 'urf bukanlah kebiasaan alami sebagaimana yang berlaku dalam kebanyakan adat, tatapi muncul dari suatu pemikiran dan pengalaman, seperti kebiasaan mayoritas masyarakat pada daerah tertentu. ${ }^{54}$

Dilihat dari objeknya 'urf dibagi kepada; al-'urf al-laf\$iy dan al-'urf al'amaliy. Al-'urf al-laf§iy adalah kebiasaan masyarakat dalam mempergunakan lafal/ ungkapan tertentu dalam mengungkapkan sesuatu, sehingga makna ungkapan itulah yang difahami dan terlintas dalam pikiran masyarakat. Contohnya: uangkapan "daging" yang berarti daging sapi. Pada hal kata-kata "daging" mencakup seluruh daging yang ada. Apabila seseorang mendatangi penjual daging, lalu pembeli mengatakan "saya mau beli daging satu kilogram", pedagang itu langsung mengambilkan daging sapi, karena kebiasaan masyarakat setempat telah mengkhususkan penggunaan kata daging pada daging sapi. Al-'urf al'amaliy adalah kebiasaan masyarakat yang berkaitan dengan perbuatan. Contohnya: kebiasaan libur pada harihari tetentu dalam satu minggu, kebiasaan masyarakat tertentu memakan makanan khusus atau meminum minuman tertentu dan kebiasaan masyarakat dalam memakai pakaian tetentu dalam acara-acara khusus. Seperti juga dalam masalah juala beli, misalanya kebiasaan masyarakat dalam berjual beli bahwa barang barang yang dibeli itu diantarkan ke rumah pembeli oleh penjual, seperti beli lemari es. Contoh lain, ada kebiasaan masyarakat mengambil barang dan membayar uang, tanpa ada akad secara jelas, seperti yang berlaku di swalayan. 
Menurut Hasbi Ash-Shiddieqy mengikuti pendapat Abu Hanifah bahwa 'urf itu adalah hujjah untuk menetapkan hukum. ${ }^{55}$ Di antara hukum di dasarkan 'urf ialah membeli buah-buahan di atas pohon dikala sudah matang sebagian. Pegangan yang dijadikan dasar ialah meninggalkan yang dipandang buruk, memperhatikan mu'amalah manusia dan yang telah menjadi tata hidup manusia yang baik. Ia menjalankan qiyas, kalau pada suatu tempat tak baik dijalankan, ia mempergunakan istihsan, kalau tak dapat ia kembali pada mu'amalah yang berlaku di antara manusia.

Lebih lanjut menurut Hasbi AshShiddieqy bahwa terdapat lima prinsip yang memungkinkan hukum Islam berkembang dalam mengikuti perkembangan zaman, yaitu; pertama; prinsip ijma'. Kedua, prinsip qiyas. Ketiga; maslahah al-mursalah. Keempat; pemeliharaan 'urf. Kelima; berubahnya hukum dengan berubahnya masa. ${ }^{56}$ Prinsip ini dengan jelas memperlihatkan betapa pleksibelnya hukum Islam.

\section{PENUTUP}

Muhammad Hasbi Ash-Shiddieqy lahir di Lhokseumawe, Aceh Utara pada tanggal 10 Maret 1904 ditengah-tengah keluarga ulama pejabat. Ia telah khatam mengaji al-Qur'an dalam usia delapan tahun. Memang harapan orang tuanya anaknya menjadi seorang ulama. Pertimbangannya bukan saja untuk meneruskan tradisi leluhur tetapi juga kedudukan dan penghargaan terhadap ulama memang tinggi di mata masyarakat, khususnya di Aceh. Dan aktifitas menulis telah dimulai sejak tahun 1930-an. Karya tulisnya yang pertama berjudul Penoetoep Moeloet. Pada tahun 1933 ia menulis artikel dalam Soeara Atjeh. Pada tahun 1937, ia memimpin dan sekaligus menjadi penulis semua artekel majalah bulanan al-Ahkam, majalah Fiqh Islamiy, yang diterbitkan oleh Oesaha Penoentoet di Kutaraja. Pada tahun 1939, ia menjadi penulis tetap pada majalah bulanan Pedoman Islam yang diterbitkan di Medan. Setelah berdiam di Yogyakarta, sejak tahun 1951, karya tulisnya sangat meningkat. Pada tahun 1961, ia merampungkan naskah Tafsir al-Nur (30 jilid), tahun1968 meneyelesaiakan naskah Mutiara Hadits (8 jilid) pada tahun 1971 naskah Koleksi Hadits Hukum (11 jilid). Di samping menulis buku yang bejilid-jilid, juga ia menulis artikel-artikel yang dimuat dalam majalah, al-Hikmah, Panji Masyarakat, Suara Muhammadiyah, al-Jami'ah, Sinar Darussalam. Pada tahun 1963 ditunjuk sebagai wakil ketua lembaga Penyelenggara Penterjemahan Kitab Suci al-Qur'an berdasarkan Surat Keputusan Menteri Agama No. 26 Tahun 1963. Dan masih banyak karyakaryanya yang lain seperti, Pengantar Hukum Islam, Peradilan dan Hukm Acara Islam, Syariat Islam Menjawab Tantangan Zaman, Filsafat Hukum Islam dan lain-lain.

Syarat-syarat dan tingkatan mujtahid menurut Hasbi Ash-Shiddieqy sebagai berikut: menguasai ilmu bahasa Arab dengan segala cabangnya, mengetahui 
nass al-Qur'an, mengetahui nass alhadif, mengetahui maqasid al-syari'ah. Dan Mujtahid itu terbagi dalam empat tingkatan, yaitu: mujtahid fiy al-syar'i, mujtahid fiy al-ma@hab, mujtahid fiy al-masa'il, dan mujtahid muqayyad.

Menurut Hasbi Ash-Shiddieqy bahwa ijma', qiyas, Istihsan, maslahah al-mursalah, dan 'urf merupakan sebuah metode atau sarana dalam mengistinbatkan hukum syara' dalam melahirkan produk pemikiran hukum Islam. Namun, para ulama berbeda pendapat tentang mempergunakan ijma', qiyas, Istihsan, maslahah al-mursalah, dan 'urf dalam mengistimbatkan hukum.

\section{Catatan Akhir :}

${ }^{1}$ Ijtihad merupakan upaya penafsiran dalam memahami al-Qur'an dan hadis dengan mempertimbangkan seluruh makna serta nilainilai yang terkandung di dalamnya. Prof. Dr. H. Minhajuddin MA, Pengembangan Metode Ijtihad dalam Perspektif Fikih Islam, pada Pidato Pengukuhan Guru Besar Tetap dalam Ilmu Fikih/Ui-1 Fikih pada Fakultas Syari'ah IAIN 'Alauddin" disampaikan pada Rapat Senat Terbuka Luar Biasa IAIN 'Alauddin" Makassar pada hari Senin, 31 Mei 2004.

1 Abiy 'usa ${ }^{3}$ A A¥mad ibn $\mathrm{Far}^{3} \mathrm{~s}$ ibn Zakar³yyah, Nu'jam Maqayis al-Lughah, Juz, I., (Beirut: Dar al-Fikr li al- ${ }^{\circ} a b a ' a h$ wa al-Nasyr, 1979), h. 486.

${ }^{1}$ H. Minhajuddin, Posisi Fiqh Muqaran, (Fiqh Perbandingan dalam Penyelesaian Masalah Ikhtilafiyyah), (Makassar: CV. Berkah Utami, 1999), h. 67.

${ }^{1}$ Wahbah Zu¥asliy, 'Ilm $U_{i}$-l al-Fiqh alIslamiy, (Juz II., Beirut: Dar al-Fikr, 1986), h. 1038.

${ }^{1}$ Zakariya al-Anjariy, Ghaya ${ }^{-}$al-Wui-l, (Singapura: al-'arama ${ }^{3} n$, t. th.), h. 147. Setiap terungkap istilah ijtihad dalam pembahasan ilmu $u_{i}$-l al-fiqh bermakna usaha-usaha maksimal yang dilakukan para ulama fikih untuk merumuskan pemikiran-pemikiran fikih, baik berupa hasil pemahaman terhadap teks lafal alQur'an dan al-Sunnah, maupun hasil analisis terhadap persoalan-persoalan aktual yang mereka hadapi. Lebih lanjut Zakariya al-Anjariy ungkapkan bahwa, kekuatan hasil ijtihad tersebut adalah «anniy, yakni punya peluang benar dan salah, dengan dugaan terkuat pada benarnya, bukan pada salahnya. Ibid. Sejalan dengan itu, al-Gazaliy menekankan bahwa hasil ijtihad itu harus diyakini kebenarannya, baik oleh mujtahidnya sendiri, maupun orang-orang yang mengikuti pendapat-pendapatnya itu. AlGazaliy, al-Mujtaifa min "ilm al-U;-l, (Jilid II; Beirut: Mus ${ }^{-}$afa Mu¥ammad, 1356), h. 101 Hasil ijtihad ini «anniy dan kesimpulan tersebut diakui oleh para ulama, termasuk al-Gazaliy sendiri. Akan tetapi, jika seorang mujtahid sudah mengambil suatu kesimpulan lewat kajian ijtihad-nya, maka dia harus menyakini bahwa hasil ijtihad-nya itu yang paling benar di antara hasil-hasil ijtihad lainnya. Menurut Wahbah Zu¥a3 liy bahwa ijtihad itu merupakan nafasnya hukum Islam. Wahbah Zuha ${ }^{3} l i y, a l-$ Was $^{3-} f^{3} U_{i-l}$ al-Figh al-Islamiy, (Damaskus: Dar al-Kitab, 1978), h. 529. Bila Ijtihad terhenti, maka dinamika hukum Islam juga terhenti, dan akan terus tertinggal oleh perkembangan budaya kehidupan manusia, yang setiap saat melahirkan persoalan-persoalan baru dan menuntut jawabanjawaban yuridis dari para ulama fikih. Mereka yang bekerja keras dalam memikirkan masalahmasalah hukum ini biasa disebut mujtah $^{3} d$, yakni ulama fikih yang mengerahkan seluruh potensi intelektualitas serta wawasannya untuk melahirkan pemikiran-pemikiran hukum Islam. Nadiyah $\operatorname{Syar}^{3 \mathrm{f}}$ al-'Umariy, al-Ijtihad fiy alIslam, (Beirut: Muassasah al-Risalah, 1981), h. 57. Akan tetapi, tidak semua orang dapat melakukan ijtihad, karena untuk melakukan tugas sekral tersebut diperlukan kualifikasi keilmuan yang memadai.

${ }^{1}$ Wahbah Zu¥a ${ }^{3}$ liy, op. cit., h. 1039.

1 'Abd al-Wahhab Khallaf Khallaf, 'Ilmu U;ul al-Fiqh, (Jakarta: Al-Majlis al-A'la alIndun³siyyah li al-Da'wah al-Islamiyyah, 1972), h. 216 . 
1 Pengertian lain yang dikemukakan oleh Mu¥ammad Ab- Zahrah ialah mengerahkan segala kesungguhan dan mencurahkan segala kemampuan, baik dalam upaya menggali hukumhukum Syara' maupun dalam upaya penerapannya, Mu¥ammad Ab- Zahrah, $U_{i}-l$ alFiqh, (Cairo: Dar al-Fikr al-'Arabiy, t.th.), h. 301 .

${ }^{1}$ Mu¥ammad M-sa Tuwana, Al-Ijtihad wa Madza |ajatina ilaiyhi $f^{3}$ |adzih al-'A;r, (Mesir: Dar al-Kutub al-|lad³tsah, 1972), h. 98.

1 T. M. Hasbi Ash-Shiddieqy, Pengantar Ilmu Fiqh, (Cet. II; Semarang: PT. Pustaka Rizki, 1999), h. 200. Ia juga mengatakan bahwa Ijtihad dalam putusan Hakim (Pengadilan) ialah jalan yang diikuti hakim dlam menetapkan hukum, baik yang berhubungan dengan nai undang-undang atau atau pun dengan mengistinbatkan hukum yang wajib diterapkan di waktu tak ada $n a$;. Ibid

${ }^{1}$ T. M. Hasbi Ash-Shiddieqy, Pengantar Hukum Islam, (Jakarta: Bulan Bintang, 1980), h. 65 .

${ }^{1}$ Minhajuddin, Posisi Fiqh Muqaran (Fiqh Perbandingan dalam Penyelesaian Masalah Ikhtilafiyyah), (Makassar: CV. Berkah Utami, 1999), h. 72.

${ }^{1}$ QS: Al-N-r (24) : 1

لامسـاغ للأجتهـاد فى (tidak ada ijtihad pada tempat-tempat yang telah ada $n_{i j}$ ) Hasbi Ash-Shiddieqy, opcit., h. 66 .

${ }^{1}$ Menurut Ma¥m-d Syalt-t, kedua macam tersebut dalam pengertian yang sebenarnya hanya terjadi pada masa pemerintahan Abu Bakar dan Umar ibn $\mathrm{Kha}^{--} \mathrm{ab}$. Kebebasan berfikir serta sistem musyawarah terlaksana dengan baik. Sedangkan masa sesudahnya, telah terjadi perpecahan dikalangan umat Islam. Lihat Ma¥m-d Syalt-t, Al-Islam 'Aqidah wa alSyari'ah, terjemahan Fahruddin HS., Aqidah dan Syari'at Islam, (Jakarta: Bina Aksara, 1985), h. 301-302.

${ }^{1}$ Kebutuhan terhadap adanya orang-orang tertentu yang terlatih dan mampu melakukan ijtihad secara mandiri (ijtihad fardiy) sangat penting, tetapi bila dilihat dari segi dampaknya terhadap kepentingan kehidupan bersama, ijtihad fardiy belum efektif. Mungkin karena faktor inilah, Mu¥ammad al-Gazaliymenilai ijtihad fardiy yang berlebihan dan tidak terkontrol dan akan menimbulkan kekacauan. Mu¥ammad alGazaliy, Mi'ah cu'al 'an al-Islam, terjemahan Muhammad Tohir dan Abu Laila, Al-Gazali Menjawab 40 Soal Islam Abad 20, (Bandung: Mizan, 1989), h.156-157.

${ }^{1}$ T.M. Hasbi Ash-Shiddieqy, Pengantar Hukum Islam, (Semarang: PT. Pustaka Putra, 1997), h. 163-164.

${ }^{1}$ Ijtihad fardiy dan ijtihad jama'iy dibenarkan syara' dan dihargai dan ke duanya mempunyai dasar. Ibid., H. 164-165

${ }^{1}$ Ibid., h. 204

${ }^{1}$ Menurut Hasbi ash-Shiddieqy bahwa alSyaf'iy mengharuskan mujtahid menghapal seluruh al-Qur'an. Ibid., h. 205

${ }^{1}$ Abiy Is¥aq al-Sya-ibiy, Al-Muwafaqat $f^{3}$ $U_{i-l}$ al-A¥kam, ( t,tp.,: Dar al-Rasyad al'ad³sah, t.th.,), h. 59.

${ }^{1}$ Ibid.

1 Yang dimaksud dengan pensyaratan keagamaan adalah aspek-aspek legalitas serta integritas keagamaan yang dimiliki seorang $m u j t a h^{3} d$. Seorang mujtah $^{3} d$ dalam fikih Islam harus memenuhi kualifikasi-kualifikasi, yakni: Pertama; Beragama Islam, baligh dan berakal. Mu¥ammad ibn Isma³ al-can'aniy, Irsyad alNuqad ila Ta Ta $^{3} r$ al-Ijtihad, (t.tp.: Dar alSalafiyyah, t. th.), h. 8. Kedua; Adil dan senantiasa menjauhi perbuatan dosa yang akan merusak keadilannya itu. Al-Gazaliy, op. cit., h. 102. Kedua persyaratan di atas diperlukan untuk menjamin kejujuran para mujtahid dalam ijtihadnya, serta kualitas kebenaran yang dirumuskannya lewat ijtihad mereka, serta kepercayaan masyarakat terhadap kebenaran hasil ijtihad-nya.

${ }^{1}$ Setiap mujtahid harus memiliki kualifikasi keilmuan yang diperlukan dalam proses ijtihadnya. Persyaratan-persyaratan tersebut, Wahbah Zu¥a3liy simpulkan, yakni: Pertama; Seseorang mujtahid harus paham dengan baik makna ayat-ayat hukum yang tertuang dalam alQur'an, baik makna kebahasaannya, maupun syar'inya. Seorang mujtah $^{3} d$ tidak dituntut untuk menghafal seluruh ayat-ayat al-Qur'an, dan juga 
tidak dituntut untuk memnghafal seluruh ayatayat hukum. Cukup bagi dia dengan mengetahui tempat ayat-ayat hukum tersebut, sehingga dapat mencarinya dengan mudah saat dia perlu. Kedua; Seorang mujtahid juga harus memahami dengan baik makna hadis-hadis hukum, baik makna kebahsaannya maupun makna syar'inya. Wahbah Zuha3liy, al-Was ${ }^{3^{-}}$, op-cit., h. 487. Yang dimaksud dengan makna kebahasaan adalah makna kosa kata bahasa Arab yang digunakan alQur'an untuk menyampaikan pesan-pesan hukumnya, serta perubahan-perubahan makna yang ditimbulkan oleh perubahan-perubahan bentuk kata. Sedang yang dimaksud dengan makna syar'i adalah makna hukum yang terungkap dalam lafal-lafal ayat, baik tersurat, tersirat maupun yang ditunjukkan oleh ungkapan itu. Seorang mujtahid juga harus menguasai dengan baik bentuk-bentuk ungkapan al-Qur'an, seperti bentuk, 'amm dan khas, $m u^{-} l a q^{3}$ dan muqayyad, haq ${ }^{3} q i$ dan majazi, dan juga kasuskasus nasakh antara satu ayat dengan ayat yang lain. Abd. Al-Mun'3m al-Namr, al-Ijtihad, (Mesir: al-Haiah al-'Amah al-Mi;riyyah, 1987), h. 181.

${ }^{1}$ Menguasai bahasa Arab dengan segala cabangnya. Untuk itu harus ditunjang dengan pengkajian dan penela'ahan seluk beluk kesusasteraan Arab baik yang berbentuk prosa maupun puisi. Ia harus mampu membedakan lafas yang $k h a_{i}$ dengan yang 'amm, yang $h a q^{3} q a h$ dengan yang majaß, yang mutasyabih dengan yang mu¥kam dan lain sebagainya. Hal ini adalah ma'lum karena yang dijadikan dasar pengambilannya adalah al-Qur'an dan al-lad ${ }^{3} £$ yang berbahasa Arab itudan ia harus bisa memahamkannya sebagaimana pemahaman orang-orang berbahasa Arab. Minhajuddin, op. cit., h. 70 .

${ }^{1}$ Mengetahui $n a_{i i}$ al-Qur'an perihal hukumhukum syari'at yang dikandungnya, ayat-ayat hukum dan cara mengistibatkan hukum dari padanya. Juga harus mengetahui asbab al-nu§-l, $n a s^{3} k h$-manskh, ta'wil dan tafsir dari ayat-ayat yang hendak di-istimba ${ }^{-}$-kan. Ayat-ayat hukum itu tidak banyak. Dalam hal ini, bagi seorang mujtahid sekurang-kurangnya dapat mengumpulkan ayat-ayat yang berhubungan masalahnya. Misalnya ayat-ayat yang berhubungan dengan masalah shalat, zakat, puasa, munakahat, mu'amalat, jinayat dan lain sebagainya. $N a_{i i}$ dari al-¥ad ${ }^{3} £$ yang memberikan penafsiran dan penjelasan ayat-ayat tersebut tidak boleh dilalaikan. Ibid., h. 71 .

${ }^{1}$ Mengetahui $\quad n a_{i i} \quad a l-¥ a d^{3} £ . \quad$ Yakni mengetahui mengetahui hukum syari'at yang didatangkan oleh al-¥ad ${ }^{3} £$ dan mampu mengeluarkan (meng-istimba ${ }^{-}$-kan) hukum perbuatan orang mukallaf dari padanya. Di samping itu, ia harus mengetahui derajat dan nilainya seperti mutawatir, ahad, $; a h^{3} h$, ¥asan dan « $a^{\prime 3} f$. Iasan dan «'3f juga harus mengetahui keadaan perawinya, mana yang fiqah (terpercaya) hingga dapat digunakan

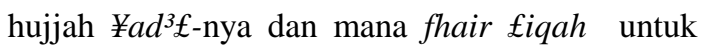
ditolak $¥ a d^{3} \mathcal{f}$-nya. Seorang mujtahid tidak dituntut untuk mengetahui seluruh $¥ a d^{3} £$ yang telah dinukil dalam dewan-dewan $¥ a d^{3} £$. Tetapi cukuplah jika ia sanggup menghimpun $¥ a d^{3} \mathcal{E}$ $¥ a d^{3} \mathcal{E}$ yang berkaitan dengan masalah-masalah tertentu, seperti $¥ a d^{3} \mathcal{E}$ - $¥ a d^{3} \mathcal{E}$ yang berhubungan dengan mu'amalat, ibadat, manakahat atau jinayat. Ibid.

${ }^{1}$ Mengetahui maqaiid al-syari'ah, tingkah laku dan adat kebiasaan manusia yang mengandung maslahat dan ke-mи«arat-an dan sanggup mengetahui 'illat hukum serta bisa menganalogi suatu peristiwa dengan peristiwa lain. Ibid.

${ }^{1}$ Mujtah $^{3} d f^{3}$ al-Syar'i, yaitu orang-orang yang berkemampuan meng-istimba ${ }^{-}$-kan seluruh masalah syari'at yang hasilnya diikuti dan dijadikan pedoman oleh orang-orang yang tidak sanggup ber-ijtihad. Merekalah yang membangun ma@hab-ma@hab tertentu. Oleh karena ijtihad yang mereka lakukan itu sematamata hasil usahanya sendiri, tanpa mencangkok dari pendapat orang lain. Maka mereka juga disebut Mujtah $^{3} d$ Mustaq ${ }^{3}$ (berdiri sendiri). Mereka itu antara lain, Imam Ab- lan $^{3} f a h$, Imam Malik, Imam Syafi'², Imam A¥mad bin lambal (pendiri ma@hab empat), Imam al-Auza'i, Imam Da-d al-"ahiriy, dan Ja'far al-фadiq. Mujtah $^{3} d f^{3}$ $a l-M a \odot h a b$ ialah Mujtahid yang hasil ijtihad-nya tidak sampai membentuk ma@hab tersendiri. 
Akan tetapi, mereka cukup mengikuti salah seorang imam ma@hab yang telah ada dengan beberapa perbedaan, baik dalam beberapa masalah yang utama maupun dalam beberapa masalah cabang. Misalnya Imam Ab- Y-suf dan Mu¥amad ibn ’asan adalah Mujtah' ${ }^{3} \mathrm{~d}$ fi alMaOhab 'anafiy dan Imam al-Maßaniy adalah Mujtah $^{3}$ d fiy MaOhab Syafi's. Mujtah ${ }^{3} d$ fiy alMasa'il ialah Mujtahid yang mengarahkan ijtihad-nya kepada masalah tertentu dari suatu ma@hab bukan kepada dasar-dasar pokok yang bersifat umum. Misalanya al- ${ }^{\circ}$ ahawiy, Mujtahid dalam Ma@hab |anafiy, Imam al-Gaßaliy, Mujtahid dalam Ma@hab Syafi' ${ }^{3}$ dan al-Khiraqiy, Mujtahid dalam ma@hab |ambaliy, dan Mujtah $^{3} d$ Muqayyad ialah mujtahid yang mengikatkan diri dan menganut pendapatpendapat Ulama Salaf dengan mengetahui sumber-sumber hukum dan dalalah-dalalah-nya. Mereka mampu menetapkan yang lebih utama di antara pendapat-pendapat yang berbeda-beda dalam suatu ma@hab dan dapat membedakan antara riwayat yang kuat dan yang lemah. Mereka itu antara lain al-Kharakhiy, Mujtahid dalam ma@hab Hanafiy, al-Rafi'3 dan alNawawi, Mijtahid dalam ma@hab Syafi's. T. M. Hasbi Ash-Shiddieqy, Pengantar Hukum Islam, (Jakarta: Bulan Bintang, 1963), h. 38-39. Minhajuddin, op. cit., h. 72.

${ }^{1}$ Al-Qur'an kitab yang jami' dan bersifat kulli, al-Qur'an menerangkan segala keperluan manusia, tidak ada sesuatu aturan yang dikehendaki, atau dibutuhkan umat yang tidak terdapat pokoknya di dalam al-Qur'an. Oleh Karena itu, perlulah seseorang Mujtahid memperhatikan al-Qur'an dahulu sebelum menetapkan hukum. Dan al-Qur'an memperkenalkan hukum-hukumnya dengan cara kulli, yakni suatu penetapan dapat kita pergunakan untuk menetapkan hukum bagi berbagai kejadian. Tegasnya al-Qur'an sebagai dasar dari segala dasar hukum bersifat kulli. $\mathrm{T}$. M. Hasbi Ash-Shiddieqy, Pengantar Hukum Islam, (Jilid I; Jakarta: Bulan Bintang, 1980), h. 191

${ }^{1}$ Al-Gazaliy, al-Mustaifa mi 'Ilm al- $U_{j}-l$, (Juz II; Beirut: Dar al-Fikr, t.th.), h. 101.
${ }^{1}$ Rukun ijma' ada lima, yaitu: pertama; yang terlibat dalam pembahasan hukum syara' melalui ijma' tersebut adalah seluruh mujtahid. Apabila ada di antara mujtahid yang tidak setuju, sekalipun jumlahnya kecil, maka hukum yang dihasilkannya itu tidak dinamakan hukum ijma'. Kedua; Mujtahid yang terlibat dalam pembahasan hukum itu adalah seluruh mujtahid yang ada pada masa tersebut dari berbagai belahan dunia Islam. Ketiga; kesepakatan itu diawali setelah masing-masing mujtahid mengemukakan pandangannya. Keempat; hukum yang disepakati itu adalah hukum syara' yang bersifat aktual dan tidak ada hukumnya secara rinci dalam al-Qur'an. Kelima; sandaran hukum ijma' tersebut haruslah al-Qur'an dan hadis Rasulullah Saw. Wahbah Zu¥ailiy, Ui-l al-Fiqh al-Islamiy, (Beirut: Dar al-Fikr, 1986) h. 491-495

${ }^{1}$ Abdul Wahhab Khallaf, "Ilm Ui-l al-Fiqh, (Kuwait: Dar al-Qalam, 1983), h. 40

${ }^{1}$ Mu¥ammad ibn '2liy ibn Mu¥ammad alSya-kaniy, $\mathrm{Na}^{3} \mathrm{l}$ al-A-${ }^{-} \mathrm{ar}$, (Jilid VII; Beirut: Dar al-Fikr, 1978), h. 65. Menurut Mu'tazilah, ijma' tidak mungkin terjadi, karena tidak mungkin menghadirkan seluruh mujtahid pada suatu masa dari berbagai belahan dunia Islam untuk berkumpul, membahas suatu kasus dan menyepakatinya bersama. Kalangan Syi'ah, ijma' tidak mereka terima sebagai hujjah, karena pembuat hukum menurut keyakinan mereka adalah imam yang mereka anggap $m a^{\prime} ;-m$ (terhindar dari dosa). Ulama Khawarij dapat menerima ijma' sahabat sebelum terjadinya perpecahan politik di kalangan sahabat.

${ }^{1}$ Hasbi Ash-Shiddieqy, op-cit., h.205

${ }^{1}$ Menurut Hasbi Ash-Shiddieqy untuk menghindari berlanjutnya perbedaan faham tentang ijma', ia menekankan perlu dikembalikan pengertian ijma' kepada makna harfiahnya seperti yang dipahami pada masa awal Islam. Pada waktu itu, makna ijma' ialah permufakatan para uli al-Amri atau Ahl al-Halli wa al-'Aqdi tentang urusan yang menyangkut kemaslahatan umum. Jadi ijma' ialah hasil musyawarah bulat mufakat anggota Ahl al-Halli wa al-'Aqdi. Nourouzzaman Shiddieqy, op. cit., h.119. Ahl alHalli wa al-'Aqdi, yang al-Mawardi menyebutnya Ahl al-Ikhtiyar dan al-Bagdadiy 
menemakannya Ahl al-Ijtihad, terdiri atas orangorang yang mendapatkan kepercayaan rakyat untuk memilih Kepala Negara. Menurut alNawawi, dalam al-Minhaj, para anggota Ahl alHalli wa al-'Aqdi terdiri dari para ulama, kepalakepala urusan pemerintahan dan pemuka-pemuka masyarakat yang mudah berkumpul untuk bersidang. Ibid., 120.

${ }^{1}$ Yang pertama beranggotakan para wakil rakyat yang terdiri atas para pemuka dan tokoh masyarakat. Mereka tidak disyaratkan mempunyai kemampuan ber-ijtihad seperti yang dituntut oleh ilmu fikih, tetapi dipercayai oleh masyarakat. Yang kedua ialah sebuah lembaga yang beranggotakan para ulama dan ilmuwan dari berbagai cabang ilmu pengetahuan, yang mempunyai kemampuan untuk ber-ijtihad, seperti yang disyaratkan oleh ilmu fikih. Ibid.

${ }^{1}$ ibid.

${ }^{1}$ Qiyas menurut bahasa berarti ukuran, mewataskan, Hasbi Ash-Shiddieqy, Pengantar Hukum Islam, op. cit., h. 215. Juga berarti mengetahui ukuran sesuatu, membandingkan atau menyamakan sesuatu dengan yang lain. Muh¥ammad al-Sya-kaniy, op. cit., h.173. Sedangkan menurut Istilah memberlakukan hukum asal kepada hukum furu' disebabkan kesatuan 'illat yang tidak dapat dicapai melalui pendekatan bahasa saja. фadr al-Syari'ah, Tanq ${ }^{3} h$ al-Ui-l, ( Jilid II; Makkah al-Mukarramah: Maktabah al-Baz, t. th.) h. 2 Menurut Hasbi Ash-Shiddieqy bahwa qiyas ialah menghubungkan sesuatu pekerjaan kepada yang lain tentang hukumnya, karena kedua pekerjaan itu bersatu pada sebab, yang menyebabkan bersatu pada hukum. Hasbi Ash-Shiddieqy, loc. cit.

${ }^{1}$ Al-Gazaliy, Al-Mustaifa f3 al-'Ilm al-U;-l, ( Jilid II; Beirut: Dar al-Kutub al-'Ilmiyyah, t.th.), h. 54 Lihat juga Tajuddin Abd Wahhab alSubkiy, Jam'u al-Jawamiy, (Jilid II; Beirut: Dar al-Fikr, 1974), h.177.

${ }^{1}$ al-Sya-kaniy, op. cit., h. 174

${ }^{1}$ Hasbi Ash-Shiddieqy, op. cit., 216

${ }^{1}$ Isti¥san menurut bahasa menganggap baik (memandang baik sesuatu), juga berarti mencari yang lebih baik untuk diikuti. Hasbi AshShiddieqy, Filsafat Hukum Islam, (Jakarta:
Bulan Bintang, 1975), h. 300. Sedangkan menurut Istilah sebagaimana yang dikemukakan oleh Imam al-Sya- ibiy yang mengikuti pendapat imam Malik mendefenisikan isti¥san dengan

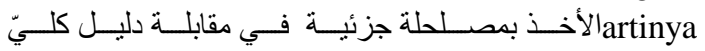
"memberlakukan kemaslahatan juz'i ketika berhadapan dengan kaidah umum". Ab- Is¥ak alSya-ibiy, Al-Muwafaqat $f^{3} U_{i}-l$ al-Syar ${ }^{3} a h$, (Jilid IV; Beirut: Dar al-Fikr, t.th. ), h. 206

${ }^{1}$ QS. Al-Baqarah, 2: 185.

${ }^{1}$ Ibn ’azm al-Andal-siy, Al-I¥kam fiy $U_{i}-l$ al-A¥kam (Jilid IV; Beirut: Dar al-Fikr, t. th.), h. 759.

${ }^{1}$ Mu¥ammad ibn '2liy ibn Mu¥ammad alSya-kaniy, Irsyad al-Fuh-l, (Beirut: Dar al-Fikr, t. th.) h. 212 .

${ }^{1}$ Alasan mereka, sebagaimana yang dikemukakan Imam Syaf'iy adalah: Pertama; hukum syara' itu ditetapkan berdasarkan $n a_{i i}$ (alQur'an dan Sunnah) dan pemahaman terhadap $n_{i i}$ melalui kaidah qiyas. Isti¥san bukan $n a_{i j}$ dan bukan pula qiyas. Jika isti¥san berada di luar naii dan qiyas, maka berarti ada hukumhukum yang belum ditetapkan Allah. Hal ini tidak sejalan dengan firman Allah dalam surat alQiyamah, 37: 36. Kedua; Umat Islam dituntut untuk taat dan patuh kepada Allah dan Rasulnya dan melarang secara tegas mengikuti hawa nafsu. Islam dituntut untuk taat dan patuh kepada Allah dan Rasul-Nya, sebagaimana firman Allah dalam surat al-Nisa', 4: 59. Ketiga; Isti¥san adalah upaya penetapan hukum dengan akal dan hawa nafsu saja. Keempat; Rasulullah tidak pernah mengeluarkan fatwanya berdasarkan isti¥san. Menurut Imam Syaf'I, jika Rsulullah tidak mau menetapkan hukum berdasarkan isti¥san, maka wajib bagi umat Islam untuk tidak menetapkan hukum atas dasar isti¥san.

1 Hasbi Ash-Shiddieqy, Filsafat Hukum Islam, op. cit., h. 314.

${ }^{1}$ Ibid., h. 315

${ }^{1}$ Secara etimologi, majla¥ah sama dengan manfaat, baik dari segi lafal maupun makna. Majla¥ah juga berarti manfaat atau suatu pekerjaan yang mengandung manfaat. 'usa ${ }^{3} \mathrm{n}$

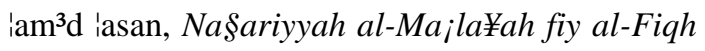
al-Islam, (Kairo: Dar al-Nah«ah al-"Arabiyyah, 1971), h. 3. Menurut Hasbi المحا فظة علي مقصود" 
الثـار ع بـ فع المفاسد عن الخلق (artinya: memelihara maksud syara' dengan jalan menolak segala yang merusakkan makhluk). Behujjah dengan majla¥ah al-mursalah terkenal yang dipakai oleh Malik. Ia berhujjah bahwasannya Allah mengutus Rasul-Rasul-Nya untuk menghasilkan manfaat bagi masyarakat. Apabila kita memperoleh suatu kemaslahatan, kuatlah persangkahan kita bahwa kemaslahatan itu dituntuy syara'. Hasbi juha mengutif pendapat alQ انّ المصلحة المرسلة في جميع المذاهب

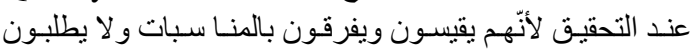
بالاعتبار شـاهدا (artinya: sebenarnya berhujjah dengan ma;la¥ah al-mursalah dilakukan oleh seluruh ma@hab, karena mereka semuanya melakukan qiyas dan membedakan antara satu dengan yang lain mengingat munasabahmunasabah hukum). Ahli $u_{i}-l$ ada yang menamakan majla¥ah al-mursalah dengan istidlal mursal atau istijlah. Secara terminologi sebagaimana yang diungkapkan oleh al-Gaßaliy mengatakan bahwa pada prinsipnya ma;la¥ah adalah mengambil manfaat dan menolak kemudaratan dalam rangka memelihara tujuantujuan syara'. Ab- 'am³ d al-Gazaliy, al-Mu;tasfa fiy 'Ilm al-Ui-l, (Jilid I; Beirut: Dar al-Kutub al'Ilmiyyah, 1983), h. 286.

${ }^{1}$ Ada beberapa syarat-syarat ma;la¥ah almursalah yang dikemukakan al-Gazaliy yang dapat dijadikan hujjah dalam mengistimbatkan hukum, yaitu: pertama; ma;la¥ah itu sejalan dengan jenis tindakan-tindakan syara'. Kedua; majla¥ah itu tidak meninggalkan atau bertentangan dengan naii syara'. Ketiga; ma;la¥ah itu termasuk ke dalam kategori majla¥ah yang «ar-riy, baik menyangkut kemaslahatan pribadi maupun kemaslahatan orang banyak dan universal, yaitu berlaku sama untuk semua orang.

1 Hasbi Ash-Shiddieqy, Filsafat Hukum Islam, op. cit., h. 336.

${ }^{1}$ Urf berarti yang baik. Para ulama membedakan antara adat dan 'urf dalam membahas kedudukanya sebagai salah satu dalil untuk menetapkan dalil syara'. A¥mad Fa¥mi Ab- Sunnah, al-'Urf wa al-'Adah fiy al-Ra'yi alFuqaha, (Mesir: Dar al-Fikr al-'Arabi, t.th.), h. 8. Menurut ulama ushul fiqh bahwa 'urf adalah artinya kebiasaan mayoritas kaum, baik dalam perkataan atau perbuatan. Ibid., Adat didefenisikan من عردمر المتكرّ artinya sesuatu yang dikerjakan secara berulang-ulang tanpa ada hubungan rasional. Sedangkan menurut Hasbi AshShiddieqy bahwa 'urf ialah keadaan yang sudah tetap pada jiwa manusia, dibenarkannya oleh akal dan diterima oleh tabiat yang sejahtera. Sedangkan adat ialah sesuatu yang dikehendaki manusia dan mereka kembali terus-menerus. Hasbi Ash-Shiddieqy, Pengantar Hukum Islam, op. cit., h. 244.

${ }^{1} \mathrm{Mu}_{i}{ }^{-}$afa A¥mad Zarqa', loc. Cit

. ${ }^{1}$ Hasbi Ash-Shiddieqy, Pengantar Hukum Islam, op. cit., h.245.

${ }^{1}$ Hasbi Ash-Shiddiegy, Syariiat Islam Menjawab Tantangan Zaman, (Jakarta: Bulan Bintang, 1966), h. 31. Ijma' yang dimaksudkan Hasbi Ash-Shiddieqy di sini bukan ijma' yang berorientasi ke masa lampau. Akan tetapi, kesepakatan ahl al-hall wa al-'aqd tentang sesuatu permasalahan hukum yang dapat saja diganti dengan adanya kesepakatan baru.

\section{DAFTAR PUSTAKA}

Alfian, Teuku Ibrahim, Perang di Jalan Allah, (Desertasi), Yogyakarta: Universitas Gajah Madah, 1981.

al-Ansariy, Zakariya, Ghaya- al-Wus-l, Singapura: al-laramain, t. th.

al-Andal-siy, Ibn jazm, Al-Ihkam fiy Us-l al-Ahkam Jilid IV; Beirut: Dar alFikr, t. th.

Ash-Shiddieqy, T. M. Hasbi, Syari'at Islam Menjawab Tantangan Zaman, Jakarta: Bulan Bintang, 1966. , Al-Islam, Ct. V; Jakarta: Bulan Bintang, 1977. , Pengantar Hukum Islam, Jakarta: Bulan Bintang, 1963. 
----------, Pengantar Ilmu Fiqh, Cet.

II., Semarang: PT. Pustaka Rizki Putra, 1999.

----------, Pengantar Hukum Islam, Semarang: PT. Pustaka Putra, 1997.

Pengantar ilmu

Perbandingan Mazhab, Jakarta:

Bulan Bintang, 1975.

-----------, Filsafat Hukum Islam,

Jakarta: Bulan Bintang, 1975.

al-Gazaliy, Ab- łamid Muhammad, al-

Mustasfa min "ilm al-Us-l, Jilid II;

Beirut: Mus ${ }^{-}$afa Muhammad, 1356

----------, Mi'ah Su'al 'an Islam,

terjemahan Muhammad Tohir dan

Abu Laila, Al-Gazali Menjawab 40

Soal Islam Abad 20, Bandung:

Mizan, 1989.

------------, al-Mustasfa fiy 'Ilm al-Us-l,

Jilid I; Beirut: Dar al-Kutub al-

'Ilmiyyah, 1983.

łasan, 'usain łamid, Na§ariyyah al-

Maslahah fi al-Fiqh al-Islam,

Kairo: Dar al-Nah«ah al-

"Arabiyyah, 1971.

Khallaf, Abdul Wahhab, "ilm Us-l Fiqh,

Kuwait: Dar al-Qalam, 1983

Minhajuddin, H., Fiqh Muqaran (Fiqh

Perbandingan dalam Penyelesaian

Masalah Ikhtilafiyyah), Makassar:

CV. Berkah Utami, 1999.

-----------, Posisi Fiqh Muqaran (Fiqh

Perbandingan dalam Penyelesaian

Masalah Ikhtilafiyyah), Makassar:

CV. Berkah Utami, 1999.

-----------,Pengembangan Metode

Ijtihad dalam Perspektif Fikih

Islam, pada Pidato Pengukuhan

Guru Besar Tetap dalam Ilmu

Fikih/Us-1 Fikih pada Fakultas
Syari'ah IAIN 'Alauddin"

disampaikan pada Rapat Senat

Terbuka Luar Biasa IAIN

'Alauddin" Makassar pada hari

Senin, 31 Mei 2004.

al-Namr, Abd. Al-Mun'im, al-Ijtihad,

Mesir: al-Haiah al-'Amah al-

Misriyyah, 1987.

al-San'aniy, Muhammad ibn Ismail,

Irsyad al-Nuqad ila Taisir al-

Ijtihad, t.tp.: Dar al-Salafiyyah, t.

th.

Shiddiqi, Nourouzzaman, Fiqh Indonesia Penggagas dan

Gagasannya, Cet. I; Yogyakarta:

Pustaka Pelajar Anggota IKAPI, 1997.

Siegel, James T., The Rope of God,

Berkeley: University of California

Press, 1969.

Sunnah, Ahmad FahmiAb-, al-'Urf wa al-'Adah fiy al-Ra'yi al-Fuqaha, Mesir: Dar al-Fikr al-'Arabi, t.th.

Sya-al-Sya ${ }^{-}$ibiy, $\quad A b-\quad$ Ishak, $A l$ -

Muwafaqat fi Us-l al-Syari'ah, Jilid

IV; Beirut: Dar al-Fikr, t.th.

Sya-al-Sya-ibiy, Abiy Ishaq, $A l$ -

Muwafaqat fi Us-l al-Ahkam, t.

tp.,: Dar al-Rasyad al-ładisah, t.th.

al-Sya-kaniy, Muhammad ibn '2liy ibn

Muhammad, Irsyad al-Fuh-l,

Beirut: Dar al-Fikr, t. th.

-----------, Nail al-A-' ar, Jilid VII;

Beirut: Dar al-Fikr, 1978.

al-Syari'ah, Sadr, Tanqih al-Us-l, Jilid

II; Makkah al-Mukarramah:

Maktabah al-Baz, t. th.

Syalt-t, Mahm-d, Al-Islam 'Aqidah ea

Syari'at, terjemahan Fahruddin HS., 
Aqidah dan Syari'at Islam, Jakarta: Bina Aksara, 1985.

Tuwana, Muhammad M-sa, Al-Ijtihad wa Madza |ajatina ilaiyhi fi |adzih al-'Asr, Mesir: Dar al-Kutub alladitsah, 1972.

'Um-al-'Umariy, Nadiyah Syarif, alIjtihad fi al-Islam, Beirut: Muassasah al-Risalah, 1981.

Zahrah, Muhammad Ab-, Us-l al-Fiqh, Cairo: Dar al-Fikr al-'Arabiy, t.th.

Zakariyyah, Abiy 'usain Ahmad ibn Faris ibn, Mu'jam Maqayis alLughah, Juz, I., Beirut: Dar al-Fikr li al- ${ }^{\circ}$ aba'ah wa al-Nasyr, 1979.

Zuhailiy, Wahbah, 'Ilm Us-l al-Fiqh alIslamiy, Juz II., Beirut: Dar al-Fikr, 1986.

, al-Wasi ${ }^{-}$fi Us-l al-Fiqh alIslamiy, Damaskus: Dar al-Kitab, 1978. 